\title{
IMPLEMENTASI AMAR MA'RUF NAHI MUNKAR DALAM KEHIDUPAN SOSIAL
}

\author{
Kartini $^{1}$; Fachrur Rizha ${ }^{2}$ \\ Institut Agama Islam Negeri (IAIN) Takengon \\ E-mail: abdi.bardan@gmail.com;fachrurrizha.sp@gmail.com
}

\begin{abstract}
Abstrak
Bagi setiap muslim tentunya diperintahkan untuk saling menyampaikan kepada kebaikan dan mencegah dari kemungkaran. Selain menjalankan perintah Allah dan Rasul-Nya, amar mar'ruf nahi mungkar juga dapat menjaga tatanan kehidupan sosial dan lingkungan masyarakat yang lebih baik. Sikap acuh terhadap kemungkaran akan mengundang azab Allah yang tidak hanya akan dirasakan pelaku mungkar, tapi juga oleh seluruh masyarakat yang ada di lingkungan kemungkaran tersebut. Sebagaimana yang terjadi pada umat-umat sebelumnya dan telah diabadikan di dalam Al Qur'an. Dalam dakwah mencegah dari kemungkaran, seorang $d a$ ' $i$ haruslah memahami madh'u yang dihadapi dan senantiasi dianjurkan tetap mengutamakan cara yang lemah lembut dalam penyampaian dakwah, meski terkadang harus berlaku tegas dalam kondisi tertentu. Orang beriman diibaratkan bagai satu tubuh, dan untuk menjaganya tetap baik, maka dibutuhkan adanya sikap saling menjaga dan mengajak kepada kebaikan dan mencegah dari kemungkaran. Implementasi dari amar'maruf nahi mungkar tidak hanya bisa dilakukan dengan cara lisan, namun juga dapat dilakukan dengan cara tulisan.
\end{abstract}

Kata kunci: Amar Ma'ruf, Nahi Munkar, Kehidupan Sosial.

\begin{abstract}
The command for every Muslim to convey to each other is good and prevent evil. In addition to carrying out the commands of Allah and His Messenger, Amar ma'ruf nahi munkar can also maintain a better order of social life and community environment. Indifference to the munkar will invite the punishment of Allah which will not only be felt by the perpetrators of the munkar, but also by the entire community in the munkar environment. As happened to the previous people and has been enshrined in the Qur'an. In da'wah to prevent evil, a preacher must understand the mad'u he is facing and always be advised to prioritize a gentle way of delivering da'wah, although sometimes he must apply firmly under certain conditions. Believers are likened to one body, and to keep it good, it is necessary to maintain an attitude of mutual care and invite to good and prevent evil. The implementation of amar'maruf nahi munkar can not only be done verbally but can also be done in writing.
\end{abstract}

Keyword: Amar M'ruf, Nahi Munkar. Social life. 


\section{PENDAHULUAN}

Dakwah merupakan upaya yang dilakukan untuk mensosialisasikan nilai Islam guna membentuk manusia yang rahmatan lil'alamin. Yakni menjadikan manusia sebagai rahmat bagi sekalian alam. Upaya dakwah dapat dilakukan dalam beberapa cara, antara lain melalui lisan (bil-lisan), tulisan (bil-kitabah) dan perbuatan (bil-alhal). Sehingga nantinya dakwah diharapkan dapat mewujudkan lahirnya umat terbaik yang Khairu Ummah dan senantiasa menjalankan aktivitas amar ma'ruf nahi munkar yang berkelanjutan. Sebagaimana yang telah dilakukan oleh Rasulullah dalam membangun keimanan ummatnya. ${ }^{1}$

Setiap mukallaf apapun organisasinya, pimpinan atau bukan pimpinan, seorang alim atau pelajar, bahkan semua jamaah Islam bagaimanapun kondisinya, memiliki kedudukan atau tidak, berkewajiban melaksanakan amar ma'ruf nahi munkar sebatas kemampuan yang dimilikinya dan pada bidang yang mungkin ia mampu menunaikannya, dimulai dari keluarga, isteri, dan anak, dan berakhir dalam skup masyarakat dan penduduk. Umat Islam memiliki kelebihan dari umat yang lain, karena amar ma'ruf nahi munkar ini. Umat umat beragama pada masa lalu berjuang untuk membela diri dari musuh atau untuk memerangi orang zalim saja. Dengan kelebihan umat Islam akan memenuhi cakrawala pada hari kiamat nanti dengan bilangannya yang banyak. Padahal ada seorang nabi hanya datang bersama satu orang kaumnya, atau seorang nabi lainnya hanya bersama dua orang. dengan amar ma'ruf nahi munkar umat ini akan menjadi hujjah (bagi umat lain), sebab mereka tidak pernah bersepakat untuk melakukan kesesatan.

Dengan kemampuan manusia, tabiat kewajiban, urusan manusia yang terkait erat dengannya berupa kesibukan hidup, tabiat masyarakat manusia dan keadaan hidup itu semua mengakibatkan bertumpuknya berbagai hal yang ma'ruf atau akumulasi berbagai kemungkaran, itu semua mengharuskan pengetahuan tentang prioritasnya hingga ia dapat mendahulukan kema'rufan paling ma'ruf dan mengingkari kemungkaran yang paling munkar, atau memprioritaskan hal yang wajib sebelum sunnah, melarang yang haram sebelum yang makruh. ${ }^{2}$

\footnotetext{
${ }^{1}$ M.Quraisy Syihab, Tafsir Al-Misbah, Pesan, Kesan dan Keserasian Al-Qur'an, (Jakarta: Lentera hati, 2006), 146.

${ }^{2}$ Adil Abdullah al-Laili asy-Syuwaikh, Bersama Kereta Dakwah, Sukses Berdakwah di Era Keterbukaan, (Jakarta: Rabbani Press, 2006). 272.
} 


\section{PEMBAHASAN}

\section{A. Metode Amar Ma'ruf Nahi Mungkar}

“Amar ma'ruf” bermakna 'seluruh ketaatan; dan yang paling utama yaitu ibadah kepada Allah semata, tiada sekutu bagi Allah, mengikhlaskan ibadah bagiAllah semata, serta meninggalkan ibadah kepada selain Allah. Sementara "mungkar" bermakna sebagai perkara yang dilarang oleh Allah dan Rasul-Nya. Sementara dakwah sendiri dapat diartikan sebagai kegiatan yang dilakukan lembaga dakwah untuk menyeru manusia pada jalan Allah, sehingga nilai-nilai Islam terwujud dalam kehidupan fardiyah, usrah, jama'ah dan ummah sampai terwujudnya tatanan Khairu Ummah. ${ }^{3}$ Seperti Allah berfirman dalam QS. Ali Imran: 110

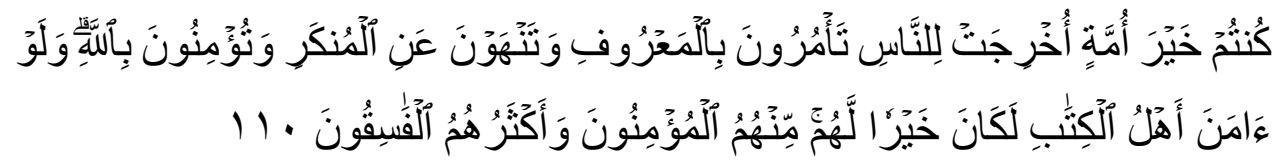

Terjemanah: "Kamu adalah umat yang terbaik yang dilahirkan untuk manusia, menyuruh kepada yang ma'ruf, dan mencegah dari yang munkar, dan beriman kepada Allah. Sekiranya Ahli Kitab beriman, tentulah itu lebih baik bagi mereka, di antara mereka ada yang beriman, dan kebanyakan mereka adalah orang-orang yang fasik."

Kemungkaran yang dibiarkan akan terus bertambah hingga menjadi kemungkaran yang lebih besar. Hal demikian juga akan menimbulkan kesan dalam benak masyarakat bahwa kemungkaran merupakan kewajaran. Lebih parah lagi jika kemungkaran dilegalisasikan, seperti usulan untuk melokalisasi judi yang belakangan ini hangat dibicarakan. Asumsi yang muncul bahwa hasil judi seolah dapat membiayai pembangunan, kenyataannya judi membangun sikap irasionalisme karena sarat unsur spekulatif dan mimpi, padahal pembangunan butuh sikap yang rasionalisme, dan jangan lupa sampai sekarang judi ilegal. Pemerintah harus dikawal agar tetap konsisten dan tak bersikap pragmatis untuk memerima dana dari sektor sektor ilegal. Harusnya pemerintah sadar bahwa judi dan praktikpraktik ilegal hanya menguntungkan sesaat tapi berbahaya untuk situasi dan waktu yang panjang, bahkan negara bisa mengalami kerawanan sosial yang sangat besar.

${ }^{3}$ Adi Sasono, Saifuddin. DKK, Solusi Islam atas Problematika Ummat, (Jakarta: Gema Insani Press, 1998), 151. 
Jika ini terjadi, tentunya akan menjadikan kemungkaran yang semakin mengkhawatirkan dan berdampak buruk bagi tatanan sosial masyarakat. Bahkan kemungkaran tersebut akan mengundang azab Allah yang tidak hanya untuk kelompok atau orang yang melakukan kemungkaran, namun juga bagi lingkungan yang acuh terhadap kemungkaran. Sebagaimana Allah berfirman yang artinya:

"Dan peliharalah dirimu dari pada siksaan yang tidak khusus menimpa orang orang yang zalim saja diantara kamu." (QS. Al-anfal;25).

Kemungkaran dalam bentuk apapun harus dicegah sedini mungkin, Pemahaman terhadap hal cara pencegahan dan tahapan-tahapannya merupakan bagian dari Fiqh Dakwah yang harus dikuasai setiap muslim. Sebab tidak mustahil, kerancuan pemahaman akan melahirkan tindakan-tindakan yang jauh dari akhlak mulia. Syekh Abdul Hamid Al-bilaly dalam Fiqh-Dakwah fi Ingkar al-munkar menjelaskan beberapa langkah yang dapat dilakukan untuk mencegah kemungkaran. ${ }^{4}$

Langkah pertama, mengenalkan tentang kemungkaran pada madh'u (komunikan). Dalam upaya tersebut harus mengedepankan cara yang lemah lembut dan tidak menggurui sehingga nasehat yang disampaikan dapat diterima dengan baik oleh madh'u. Syekhul Islam Ibnu Taimiyah rahimahullah berkata, "Barang siapa yang memerintahkan hal yang ma'ruf dan mencegah dari kemungkaran maka hendaknya dia memiliki ilmu tentang hal yang dia perintahkan dan hal yang ia larang, serta bersikap lembut dan santun ketika memerintah dan melarang. Hendaknya, ilmu didahulukan sebelum memerintah, sedangkan sikap lembut dan santun harus selalu menyertai perintah. Jika tidak berilmu maka dia tidak boleh mengerjakan segala sesuatu yang ilmu tentangnya tidaklah dia miliki”. Sungguh, Allah telah berkata kepada Musa dan Harun 'alaihimassalam (yang artinya),

"Maka berbicaralah kamu berdua kepadanya dengan kata-kata yang lemah lembut. Mudah-mudahan ia ingat atau takut." (QS. Thaha:4)

${ }^{4}$ Syekh Abdul Hamid Al-bilaly, Fiqh-Dakwah fi Ingkar al-munkar; (Surabaya; Kataelha, 2010). 63- 70 . 
Contoh kisah Fir'aun dengan Nabi Musa, yang mana Fir'aun menjalani kekuasaan sudah melampui batas Al-Qur'an mengajarkan kepada kita jika dalam berdakwah kepada penguasa yang zalim, haruslah bersifat sejuk dan lemah lembut, tidak kasar dan lantang. Karena perkataan yang lantang kepada penguasa zalim tersebut dapat memancing balasan sikap yang lebih keras dan menyebabkan terhambatnya ruang dialog atau komunikasi antara $d a^{\prime} i$ dan madh'u. Berkata lemah lembut adalah perintah Allah kepada Nabi Musa dan Harun, supaya menyampaikan Tabsyir dan Inzar, kepada Fir'aun dengan Qaulan Layyinan. Term Qaulan Layyinan terdapat dalam surah Thaha ayat 43-44, secara harfiyah berarti komunikasi yang lemah lembut.

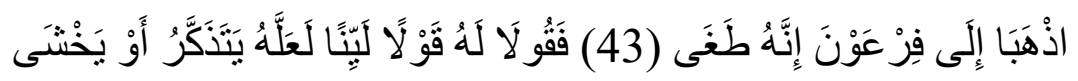

Artinya:" 43. Pergilah kamu berdua kepada Fir'aun, Sesungguhnya Dia telah melampaui batas; 44. Maka berbicaralah kamu berdua kepadanya dengan kata-kata yang lemah lembut, Mudah-mudahan ia ingat atau takut". 5

Kedua, menasehati langkah ini ditempuh setelah madh'u mengetahui hukum perbuatannya. Upaya menasehati madh'u agar bertakwa kepada Allah haruslah disampaikan dengan tutur kata yang halus dan penuh kelembutan, sebagaimana fitrahnya manusia yang suka akan kehalusan dan kelembutan. Sebagaimana dalam Surat An-Nahl ayat 125 Allah berfirman: "Serulah manusia kepada jalan Tuhanmu dengan hikmah dan pelajaran yang baik dan bantahlah mereka dengan cara yang baik".

Menurut Quraish Shihab Hikmah adalah sesuatu yang apabila digunakan dan dipraktekkan akan menghalangi terjadinya mudharat, atau kesulitan atau mendatangkan kemaslahatan dan kemudahan. Hikmah juga dimaknai sebagai ilmu amaliah dan amal ilmiah, atau dengan kata lain ilmu yang didukung oleh amal dana amal yang tepat untuk didukung oleh ilmu. ${ }^{6}$

Ketiga, Attahni (bersikap tegas dan keras). Langkah ini ditempuh ketika langkah kelemah lembutan mendapat penolakan dan penghinaan terhadap nasehat,

${ }^{5}$ M. Munir, Metode Dakwah, (Jakrta; Kencana, 2009), 166.

${ }^{6}$ Abdullah, Ilmu Dakwah, kajian ontologi, epistimologi, aksiologi dan aplikasi dakwah, (Depok: Raja Grapindo Persada, 2018), 135. 
Terkadang sikap yang keras dan tegas juga harus dilakukan oleh seorang $d a$ ' $i$ dalam menyampaikan dakwah, terlebih saat harus meluruskan sejumlah kekeliruan, bid'ah, syirik dan ushul aqidah yang menyimpang. Tidak selamanya dakwah harus disampaikan dengan cara lemah lembut, namun ada saatnya dakwah juga harus disampaikan secara tegas dan keras, meski terkadang ketegasan tersebut sering dianggap sebagai sikap yang arogan. Ketika seorang $d a^{\prime} i$ menyampaikan dakwah secara keras dan tegas maka bagi sebagian kalangan akan menilai jika $d a$ ' $i$ tersebut tidak lagi mencerminkan akhlak yang mulia, suka mengkafirkan, menyesatkan, radikal, ekstrim, wahabi, teroris dan sebagainya. Anggapan seperti ini timbul dari prinsip dakwah yang bathil berupa semboyan yang mengajak kepada persatuan kaum muslimin walaupun di atas kebathilan. Setiap hal yang berakibat memecahbelah kaum muslimin harus dijauhkan dari dakwah.

Sikap lembut dalam menyampaikan dakwah memang sebuah keharusan, namun saat menghadapi sebuah kemungkaran yang sudah merajalela, maka sikap keras dan tegas juga harus dikedepankan demi menjaga kemurnian syariat Allah. Bahkan Allah dalam Al Qur'an telah membenarkan peperangan dalam melawan golongan yang berbuat kemungkaran dan aniaya.

"Dan jika ada dua golongan dari orang" mukmin berperang, maka damaikanlah antara keduanya, jika salah satu dari kedua golongan itu berbuat aniaya terhadap golongan yang lain maka perangilah golongan yang berbuat aniaya itu sehingga golongan itu kembali kepada perintah Allah 憋” (Al-Hujurat: 9)

Keempat. dengan tangan dan kekuasaan. Langkah yang satu ini tentunya akan memberikan pengaruh yang besar dalam menerapkan amar ma'ruf nahi mungkar, sehingga upaya mecegah kemungkaran dengan tangan pun lebih didahulukan dibandingkan yang lain. Sebagaiamna dalam hadist Rasulullah yang berbunyi:

"Siapa yang melihat kemungkaran diantara kalian, hendaknya ia mengubahnya dengan tangannnya, jika ia tidak mampu maka dengan hatinya maka itulah iman yang paling lemah" (HR. Muslim).

Seperti disepakati Ibnu Muflih dalam Al-aadab Asyar'iyyah (1/219), langkah ini baru ditempuh jika langkah menasehati dengan lemah lembut dan bijaksana tidak juga membuat madh'u berubah. 
Qadhi Iyyadh, seorang ulama besar dalam Mazhab Hambali, mengajukan syarat kepada sang da'i yang melakukan dakwah dengan tangan tersebut tidak sampaikan melahirkan kemungkaran yang lebih besar, seperti pembunuhan terhadap dirinya atau orang lain. Jika demikian keadaaannya, maka cukup dengan nasehat dan ancaman (Syarah Muslim lian-nawawi II/25). Ibnu Qudamah dalam Mukhtashar Minhaj al-Qashidin, menjelaskan secara gamblang, siapa yang yakin ditimpa sesuatu yang tidak disukai, maka tidak wajib baginya mengingkari (mencegah dengan tangan), jika ia yakin akan keselamatannya maka wajib baginya.

Kaidah ini dapat disimpulkan dari sirah Nabi, untuk menghindari mudharat yang lebih besar, Rasulullah tidak memerintahkan untuk membunuh biang munafik Abdullah bin Ubay, sehingga mereka lari dari Islam, karena mengira beliau membunuh sahabatnya. Beliau juga tidak merenovasi Ka'bah dengan cara menghancurkan dan membangun ulang sesuai dengan fondasi yang diletakkan oleh Nabiyullah Ibrahim AS, untuk menghindari anggapan orang kebanyakan bahwa beliau menghina tempat suci. Apalagi banyak di antara mereka yang baru saja memeluk Islam (HR. Muslim no. 1333).

Para da'i juga disyaratkan memiliki kemampuan dan kekuasaan dalam menempuh langkah ini, seperti suami terhadap isteri, ayah terhadap anak, atau kepala negara terhadap rakyatnya. Tentu saja masing-masing $d a{ }^{\prime} i$ memiliki kapasitas yang berbeda dalam menggunakan metode ini. $^{7}$

Kelima, dengan ancaman. Langkah ini juga dibenarkan untuk dilakukan oleh $d a^{\prime} i$ dalam melawan kemungkaran. Ancaman yang dimaksud di sini tentunya ancaman yang bertujuan mengubah perilaku madh'u untuk meninggalkan kemungkaran. Ancaman seperti akan memukul atau menendang tersebut tentunya harus dihentikan ketika madh'u tidak lagi melakukan atau meninggalkan perbuatan mungkar tadi. Ibnu Qudamah mengatakan, tidak dapat dipungkiri, pemahaman $d a{ }^{\prime} i$ tentang kaidah-kaidah dalam melaksanakan amar ma'ruf dan nahi munkar sangat menentukan suksesnya dakwah, sebab seperti diungkap oleh seorang bijak, meskipun tidak diwajibkan untuk berhasil dalam dakwah namun jangan sampai dakwah kita gagal.

7 Abdullah, Wawasan Dakwah, Kajian Efistimologi, Konsepsi dan Aplikasi Dakwah, (Medan: IAIN Press, 2001), 78. 


\section{B. Keutamaan Amar Ma'ruf Nahi Mungkar}

Menyeru dalam amar ma'ruf nahi mungkar merupakan suatu kewajiban yang sifatnya fardu kifayah. Syekhul Islam Ibnu Taimiyah rahimahullah berkata, 'Barang siapa yang memerintahkan hal yang ma'ruf dan mencegah dari kemungkaran maka hendaknya dia memiliki ilmu tentang hal yang dia perintahkan dan hal yang dia larang, serta bersikap lembut dan santun ketika memerintah dan melarang". Berdasarakan penyataan tersebut dapat dipahami jika ilmu merupakan pondasi dasar dalam amar ma 'ruf nahi mungkar. Seseorang yang akan berdakwah dan menyeru kepada kebaikan, maka hendaklahlah dia memiliki ilmu terhadap apa yang dia sampaikan. Dan bahkan dia ditekankan untuk tidak mengerjakan atau memerintahkan sesuatu yang dia tidak memiliki ilmu terhadap hal tersebut.

Ibnu Taimiyah menambahkan, jika wajib hukumnya bagi orang, yang memerintahkan perkara yang ma'ruf dan mencegah dari kemungkaran, untuk melakukannya dengan ikhlas karena Allah, dengan maksud taat kepada Allah. Hendaknya pula, tujuannya adalah untuk memperbaiki orang yang diperintah, menegakkan hujjah (alasan) kepadanya, dan jangan bertujuan untuk mencari kedudukan, baik untuk dirinya maupun untuk kelompoknya, atau untuk melecehkan orang lain. ${ }^{8}$

Amar ma'rüf dan nahi munkar merupakan pilar agama yang banyak memiliki keutamaan dan kemuliaan. Antara lain:

1. Memperoleh pahala yang berlipat ganda. Sebagaimana Allah berfirman: "Tidak ada kebaikan pada kebanyakan bisik-bisik mereka, kecuali bisikan orang yang menyuruh untuk memberi sedekah, atau berbuat ma'rūf, atau mengadakan perdamaian di antara manusia. Dan barangsiapa yang berbuat demikian karena mencari keridhaan Allah, maka Kami akan memberinya pahala yang besar.” (QS. an-Nisa' [4]: 114). Imbalan pahala yan besar dalam mengerjakan Amar ma'rūf dan nahi munkar juga disampaikan Rasulullah: Barangsiapa yang menyeru kepada petunjuk, maka ia mendapat pahala seperti pahala

${ }^{8}$ Syekh AL-Allamah shalih Al- Fauzan. Al-amru bil Ma'ruf Wa 'anil Munkar, Jakarta; Pustaka At-tazkia, 2000, 14. 
orang-orang yang mengikutinya tanpa mengurangi pahala mereka sedikitpun." (HR. Muslim). ${ }^{9}$

2. Merupakan sebab terhindarnya umat dari bencana dan adzab. Rasul bersabda: "Demi Allah yang nyawaku berada di tangan-Nya, hendaklah kalian menyuruh kepada yang ma'rüf dan mencegah dari yang mungkar, jika tidak niscaya Allah akan mengirimkan adzab kepada kalian, kemudian kalian berdoa kepada-Nya akan tetapi tidak dikabulkan." (HR. al-Tirmidzi). Kita harus waspada agar tidak tertimpa azab yang menimpa, jika melalaikan kewajiban amar ma'ruf dan nahi munkar termasuk sebab tertolaknya doa dan tidak terwujudnya kemenangan. Tidak diragukan bahwa hal ini merupakan musibah besar, sebagai hukuman akibat meninggalkan kewajiban amar ma'ruf nahi munkar, di mana kaum muslimin tidak dimenangkan oleh Allah, mereka berpecah belah, musuh musuh mereka menguasai mereka dan doa mereka tidak di kabulkan oleh Allah, tidak ada daya dan kekuatan kecuali dengan pertolongan Allah. ${ }^{10}$

Amar ma'ruf dan nahi munkar merupakan sifat asasi bagi orang-orang yang beriman. Ia merupakan perwujudan dari aqidah al-walā' wa al barā' (cinta dan benci karena Allah). Allah menyifati orang-orang yang beriman dengan sifat-sifat yang indah dan mendapatkan rahmat Allah. Hal tersebut dikarenakan orang beriman senantiasa menyeru saudaranya yang lain untuk melakukan yang ma'ruf dan mencegah dari yang mungkar. Sebaliknya, tidak mencegah dari kemungkaran meskipun dengan cara yang paling ringan (dengan hati) adalah bukti tidak adanya iman dalam hati seseorang. ${ }^{11}$

\section{Ketika Amar Ma'rūf Ditinggalkan}

Sejumlah musibah yang terjadi, mulai dari bencana banjir, tsunami, gempa bumi, longsor dan sejumlah kecelakaan yang merenggut ratusan malah ribuan 2019), 35.

${ }^{9}$ Syuikh Abdul Aziz bin Buz, Keutamaan Amar Ma'ruf Nahi Munkar, (Jakarta: Darul Haq,

${ }^{10} \mathrm{Ibid}$, hal. 43

${ }^{11}$ Adil Abdullah al-Laili asy-Syuwaikh, Bersama Kereta Dakwah, Sukses Berdakwah di Era Keterbukaan, Jakarta: Rabbani Press, 2006. Hal. 66. 
korban jiwa. Belum lagi manusia mulai dikhawatirkan dengan wabah penyakit yang terus menghantui tatanan kehidupan di berbagai negara dan benua, mulai dari virus antrak, flu babi, flu burung hingga virus corona yang telah menyerang ratusan juta serta menyebabkan jutaan kematian di seluruh dunia dan terus bertambah setiap harinya.

Berbagai upaya terus dilakukan seluruh negeri untuk mengantisipasi dan menanggulangi sejumlah musibah dan bencana yang terjadi. Namun dari sejumlah kejadian tersebut sangat jarang ada yang mengakui jika itu tidak terjadi begitu saja, namun disebabkan oleh kesalahan dan dosa yang dilakukan manusia itu sendiri hingga mengundang pada kemurkaan Allah. Sebagaimana yang tertuang dalam surat Ar-Rum ayat 41, yang berbunyi:

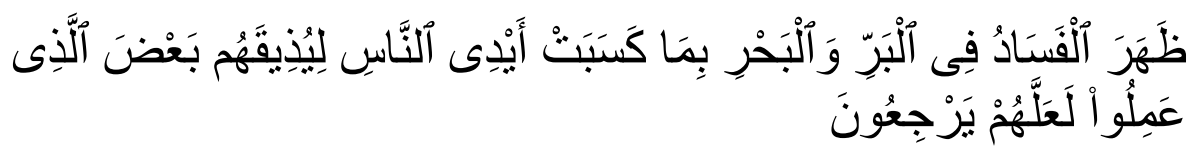

Artinya: "Telah nampak kerusakan di darat dan di laut disebabkan karena perbuatan tangan manusia, supaya Allah merasakan kepada mereka sebahagian dari (akibat) perbuatan mereka, agar mereka kembali (ke jalan yang benar)". ${ }^{2}$

Peristiwa ini juga terjadi saat kaum muslimin mengalami kekalahan dalam perang uhud. Dan kaum muslin pun bertanya-tanya penyebab kekalahan tersebut. Maka Allah berfirman: "Dan mengapakah ketika kalian ditimpa musibah (pada peperangan Uhud) sementara kalian telah menimpakan kekalahan dua kali lipat kepada musuh-musuh kalian (pada peperangan Badar), kalian berkata: 'Darimanakah datangnya (kekalahan) ini?' Katakanlah: 'Itu dari (kesalahan) kalian sendiri!'. Sesungguhnya Allah Maha Kuasa atas segala sesuatu." (QS. Ali 'Imran [3]: 165).

Ayat di atas menggambarkan kepada kita jika kekalahan yang dialami kaum muslimin ketika itu disebabkan oleh kesalahan yang mereka lakukan yaitu saat para pemanah meninggalkan posnya sebelum datang perintah dari Rasulullah. Jika kita kita melihat pada bentuk kesalahan yang dilakukan kaum muslimin ketika itu bukanlah sebuah dosa yang besar, namun dikarenakan mereka tidak mengikuti 
perintah Rasulullah dalam perang, maka kekalahan pun harus mereka terima sebagai buah dari perbuatan mereka sendiri.

Kemudian, coba kita kaitkan dengan fenomena kemungkaran yang terjadi saat ini. Sejumlah tempat maksiat seperti pelacuran, perjudian terus menjamur di setiap pelosok negeri. Bahkan pemerintah pada saat ini telah berani dengan terbuka melegalitaskan miras kepada publik, walaupun dalam hal ini banyak yang pro dan kontra tentang legalitas miras. Pornografi pun semakin berani dipertontonkan ke publik memalui media massa maupun pentas terbuka. Sistem perekonomian yang dianut oleh masyarakat juga didominasi sistem riba dan bahkan korupsi semakin subur tumbuh dan berkembang seakan sudah hilang rasa malu. Belum lagi jika kita melihat sejumlah masjid yang dibangun begitu megah di mana-mana, namun tidak sebanding dengan jumlah jamaah yang datang untuk beribadah. Banyak yang beralasan karena Covid-19 tidak boleh shalat berjamaah, aktivitas hablumminallah dan hablumminannas dibatasi sehingga kehidupan sosial di tengah masyarakat sudah memudar akibat covid.

Kemungkaran yang terjadi pun kian menyebar, bahkan hingga ke pusat pendidikan seperti perguruan tinggi. Di dunia kampus yang seharusnya mendidik dan melahirkan para ulama dan terpelajar dalam sejumlah bidang keilmuan, namun saat ini tidak jarang kampus malah berubah menjadi tempat berkembangnya komunitas yang bertentangan dan berseberangan dengan syariat Allah. Dengan alasan kebebasan berpendapat dan berfikir dan mereka mengusung paham Islam liberal sebagai pondasi keagamaan yang dianut. Belum lagi kalau kita melihat fenomena munculnya sejumlah nabi palsu dalam lingkungan masyarakat hingga aliran sesat yang kian meresahkan. Namun sesungguhnya semua kemunkarankemunkaran yang dilakukan tersebut akan mengakibatkan kerugian yang besar bagi umat manusia. Rasulullah bersabda:

"Perumpamaan orang yang berdiri di atas larangan-larangan Allah dan yang terjerumus di dalamnya, seperti kaum yang menaruh belas kasihan di atas kapal laut, sebagian mereka di atas dan sebagian lainnya di bawah. Orang yang berada di bawah kapal jika mencari air harus melewati orang yang berada di atasnya, mereka berkata: 'Jika kita melubangi pada tempat kita sebuah lubang, maka tidak mengganggu orang yang di atas kita.'. Apabila mereka (yang di atas kapal) membiarkan keinginan mereka (yang 
di bawah) hancurlah semuanya. Dan apabila mereka mencegahnya, maka selamatlah semuanya." (HR. al-Bukhari). ${ }^{13}$

Sikap lalai terhadap amar ma'ruf nahi mungkar seakan sudah terkikis dari kehidupan masyarakat kita saat ini. Mengajak orang lain kepada kebaikan atau berdakwah bagi sebagaian orang terkadang dianggap sebagai sikap ikut campur dan tidak perlu dilakukan. Amar ma'ruf dan nahi munkar dianggap melanggar HAM (Hak Azazi Manusia), jika ditegur karena kesalahan mereka menjawab, “dosa biar saya yang tanggung" mereka sangat berani dan main-main dengan dosa, seolah olah perkara dosa itu ringan bagaikan angin. Padahal mengajak dalam hal kebaikan adalah sikap yang sangat terpuji untuk dilakukan oleh sesama muslim, karena umat muslim itu pada hakikatnya bersaudara dan diibaratkan dengan satu tubuh. Sebagaimana sabda Rasulullah.

"Engkau lihat orang-orang yang beriman itu dalam hal saling menyayangi, mencintai dan berempati sesama mereka bagaikan satu tubuh. Jika salah satu anggota tubuh tersebut sakit, maka seluruh jasadnya pun merasakan tidak dapat tidur dan demam. (HR. al-Bukhari).

Hadist di atas menekankan kepada kita, jika sesungguhnya orang beriman adalah saudara dan harus saling menasehati untuk kebaikan. Bahkan Rasulullah mengibaratkan orang beriman dengan satu tubuh, yang mana setiap anggota badan dalam satu tubuh akan merasakan hal yang sama. Baik itu kenikmatan maupun rasa sakit.

Ketika seseorang membiarkan saudaranya berbuat kemunkaran dan tidak mencegahnya berarti, ia tega melihat saudaranya tergelincir ke jurang neraka. ${ }^{14}$ Dikarenakan perilaku kemungkaran yang dilakukan oleh setiap orang tidak hanya berdampak bagi dirinya saja, namun efek dari kemungkaran tersebut juga akan berdampak pada masyarakat atau lingkungannya. Untuk itu sudah menjadi kewajiban bagi setiap muslim untuk saling mencegah kemungkaran dengan saling menasehati dan mengajak ke jalan yang diperintahkan Allah dan Rasul-nya. Sebagaimana Rasulullah bersabda: "Sesungguhnya apabila umat manusia melihat seorang berbuat kezhaliman lalu mereka tidak mencegahnya, maka telah dekat

\footnotetext{
${ }^{13}$ Chalil Moenawar, Kembali kepada AL-Qur'an dan Sunnah, (Jakarta: Bulan Bintang 1956), 78.

${ }^{14}$ Hamka, Prinsip Kebijaksanaan Dakwah Islam, (Kuala Lumpur: Pustaka Melayu, 1981), 98.
} 
saatnya Allah akan menimpakan kepada mereka adzab yang menyeluruh (merata)." (HR. Abu Dawud, at-Tirmidzi, dan an-Nasa'i dengan sanad yang shahih).

\section{Saling Menasehati Dengan Kesabaran dan Kebenaran.}

Karena sabar, lemah lembut dan berilmu, termasuk kaidah amal jama'i, maka sangat penting mengingatkan hal ini kepada kawan seperjalanann dan saling nasehat menasehati. Surat Al-ashr yang bisa di jadikan sebagai ikatan janji saat mereka berpisah, menjadikan salah satu faktor penting bagi seseorang untuk menghindari kerugian, setelah iman dan amal shaleh adalah saling menasehati dalam kebenaran dan kesabaran. Dari surat Al-ashr tersebut dapat dipahami bahwa, iman dan amal sholeh berada pada satu tingkat, sedangkan saling menasehati dalam kebenaran dan kesabaran berada pada satu tingkat yang lain.

Ibnu Qayyim rahimahullah berkata, "dan mereka saling menasehati dalam kebenaran" artinya sebagian mereka menasehati yang lain sebagai bentuk pengajaran dan bimbingan, ini merupakan tingkat ketiga. 'dan mereka saling menasehati dalam kesabaran", artinya mereka bersabar karena kebenaran, sebagian mereka menasehati yang lain agar mereka bersabar dan teguh, ini merupakan tingkat keempat dan puncak kesempurnaan, sebab unutk mencapai kesempurnaan, seseorang harus sempurna dalam dirinya terlebih dahulu dan menyempurnakan yang lain, sedangkan kesempurnaannya terwujudkan dengan melakukan perbaikan amal dan ilmunya, ${ }^{15}$.

Nasehat itu tidak bisa berpadu dengan kedengkian, karena memang berlawanan, barangsiapa menasehati para pemimpin dan umat, maka ia telah terbebas dari kedengkian. Komitmen dengan jama'ah bisa membersihkan hati dari kedengkian dan kecurangan, sebab orang yang komitmen mencintai apa yang mereka cintai dan membenci apa yang mereka benci, merasa sakit karena hal yang membuat mereka sakit dan merasa gembira atas apa yang membuat mereka gembira. ${ }^{16}$

${ }^{15}$ Miftahu dari Assa'adah, Ibnul Qayyim Al-Jauziyah, Maktabatur Riyadh Al-Hadistah, (Riyadh: 2001), 45.

16 Adil Abdullah al-Laili asy-Syuwaikh, Bersama Kereta Dakwah, Sukses Berdakwah di Era Keterbukaan, (Jakarta: Rabbani Press, 2006), 130. 


\section{KESIMPULAN}

Berdasarkan uraian pembahasan di atas, maka dapat disimpulkan:

1. Umat Islam senantiasi diperintahkan untuk menerapkan amar ma'ruf nahi mungkar dalam kehidupan dana tatanan sosial masyarakat. Dalam menyeru kepada kebaikan dan mencegah kepada kemungkaran tentunya seorang $d a$ ' $i$ harus dapat memahami madh'u dengan tetap mengutamakan cara penyampaian yang lemah lembut dalam berdakwah.

2. Mendorongnya untuk melakukan kebajikan dan memerintahkan untuk meninggalkan larangan, seorang mukmin dengan mukmin yang lainnya bagai dua tangan yang saling mencuci yang lain, nuansa saling menasehati dalam kebenaran harus memalui dialog yang konstruktif, diskusi yang menghasilkan dan kritik objektif yang mencakup semua amal.

3. Sesungguhnya amar ma'ruf nahi munkar patut mendapat perhatian, karena ia mewujudkan kebaikan dan keselamatan umat. Di dalam melalaikannya terkandung bahaya besar dan kerusakan merata, tertutupnya keluhuran dan munculnya kenistaan. Allah menyatakan kedudukannya yang tinggi sampai sampai di sebagian ayat, Allah mendahulukannya di atas iman yang merupakan dasar agama dan asas Islam.

4. Proses amar ma'ruf nahi munkar bukan hanya dilakukan dengan metode lisan yang saling menasehati dengan kesabaran dan kebajikan, namun amar ma'ruf nahi munkar bisa juga dilaksanakan dengan metode tulisan.

\section{DAFTAR PUSTAKA}

Abdullah, Ilmu Dakwah, kajian ontologi, epistimologi, aksiologi dan aplikasi dakwah, Depok: Raja Grapindo Persada, 2018.

Abdullah, Wawasan Dakwah, Kajian Efistimologi, Konsepsi dan Aplikasi Dakwah, Medan: IAIN Press, 2001. 
Adi Sasono. Saifuddin, DKK, Solusi Islam atas Problematika Ummat, Jakarta: Gema Insani Press, 1998.

Asy-Syuwaikh. Adil Abdullah al-Laili, Bersama Kereta Dakwah, Sukses Berdakwah di Era Keterbukaan, Jakarta: Rabbani Press, 2006.

Al-bilaly. Syekh Abdul Hamid, Fiqh-Dakwah fi Ingkar al-munkar; Surabaya; Kataelha, 2010.

Al-Fauzan. Syekh AL-Allamah shalih, Al-amru bil Ma'ruf Wa 'anil Munkar, Jakarta; Pustaka At-tazkia, 2000.

As suhaimi. Syaikh Fawwaz bin hulayyil, Usus Manhaj Salaf fii dakwah ilallah, cet: Darul Haq, 2006.

Aziz bin Buz. Syuikh Abdul, Keutamaan Amar Ma'ruf Nahi Munkar, Jakarta: Darul Haq, 2019.

Chalil Moenawar, Kembali kepada AL-Qur'an dan Sunnah, Jakarta: Bulan Bintang, 1956.

Hamka, Prinsip Kebijaksanaan Dakwah Islam, Kuala Lumpur: Pustaka Melayu, 1981.

Miftahu dari Assa'adah, Ibnul Qayyim Al-Jauziyah, Maktabatur Riyadh AlHadistah, Riyadh: 2001.

M.Munir, Metode Dakwah, Jakrta; Kencana, 2009.

M.Quraisy Syihab, Tafsir Al-Misbah, Pesan, Kesan dan Keserasian Al-Qur'an: Jakarta: Lentera hati, 2006. 
